\title{
Maintenance energy requirements in adult and growing organisms - an unresolved problem
}

\author{
J.S. Keller \\ Warsaw Agricultural University \\ Nowoursynowska 166, 02-787 Warsaw, Poland
}

(Received 22 May 2001; revised version 2 July 2002; accepted 2 August 2002)

\section{ABSTRACT}

Metabolic rate is generally understood as the rate of heat production resulting from all oxidative processes. Classically, total metabolism has been divided into maintenance and production processes, with the assumption that they are more or less independent of each other, in other words, that these two parts of heat production add up.

Maintenance heat production is mainly expressed as a function of body size, while the energy cost of production processes is calculated per unit of product (usually protein and fat accretion). This approach can only be accepted for an adult organism whose level of physical activity is low and who may retain some fatty tissue in some periods of life, but normally is characterized by a zero protein balance and low energy expenditure.

Our general and current knowledge of bioenergetics shows that it is necessary to take into account the influence of anabolic processes on catabolism along with the impact of metabolic memory. In the field of protein metabolism the so-called anabolic increment of catabolism is a very well-known phenomenon and several research studies indicate that metabolic memory can persist for more than 30 days.

From that point of view, it is unjustified to separate maintenance and productive processes, especially in growing organisms within the same taxonomic group, unless the growth rate of their body weight is taken into account.

A new method of studying maintenance energy requirements in growing animals is therefore proposed. It is based on determination of the maximum body weight of an organism at which a given daily ration of food covers the maintenance requirements of a young animal but does not contain any food for growth.

KEY WORDS: metabolizable energy for maintenance, resting metabolic rate, nutritional memory, growth rate

\section{DEFINITIONS}

Blaxter (1972) formulated the classical definition of maintenance as a state "in which there is neither gain nor loss of nutrients by the body". Therefore, the me- 
tabolizable energy requirement for maintenance $\left(\mathrm{ME}_{\mathrm{m}}\right)$ should be defined as the amount of energy available from the daily ration of food that is able to balance anabolic and catabolic processes in a living organism, giving near-zero energy retention. This definition can only be acceptable for adult and non-producing animals.

In studies on growing and producing animals Chwalibog (1987) suggested the following definition: "the maintenance requirement of energy is the amount of metabolizable energy $\left(\mathrm{ME}_{\mathrm{m}}\right)$ needed to maintain a dynamic equilibrium of protein and fat turnover, to maintain a constant body temperature and to maintain a normal level of locomotion activity".

According to Blaxter's classical definition of maintenance formulated for adult and non-producing animals, both protein and fat balances in the body should be zero. According to the definition proposed by Chwalibog, a negative value can occur in one of the components, while the other can have a positive value of the same magnitude, giving zero total energy retention. In growing or producing animals the problem is complicated by the anabolic increment of catabolism and catabolic decrement of anabolism; both processes are specific for particular tissues (not for the whole organism as a unit) and related to the plane of nutrition.

From a different point of view, energy expenditure at the maintenance state is a sum of basal metabolic rate (BMR), dietary induced thermogenesis (DIT), and energy expenditure for "normal physical activity" (EEPA). The basal metabolic rate is usually replaced in animals by resting metabolic rate (RMR), which is greater than basal metabolic rate primarily because part of the postprandial thermogenic response is included in the RMR measurements. DIT is closely related to the quantity and quality of food consumed and normally it does not exceed the level of about $10 \%$ of ME ingested. EEPA at the maintenance level accounts for not more than $30 \%$ of the total energy expenditure of an animal, depending on a number of environmental and genetic factors (Mc Leod, 1984). Thorbek et al. (1984) stated that physical activity was even reduced during fasting in growing pigs, especially in heavier ones. Therefore RMR is the largest part of energy expenditure in a maintenance state and is normally multiplied by 1.4 for calculating the maintenance energy requirement of an adult, non-productive organism.

\section{RESTING METABOLIC RATE AND METABOLIC BODY SIZE}

The main problem related to the maintenance energy requirement seems to be the relationship between (RMR) and animal body size in comparisons made within some particular species. Nevertheless, as seen in the literature, the greatest effort so far has been focused on the formulation of some general law related to fasting metabolic rate in animals of different size in inter-species comparisons. The need for such a law was related to the fact that the metabolic rate of homeotherms 
decreases with increasing body size from $200 \mathrm{kcal} / \mathrm{kg}$ body weight in a $20 \mathrm{~g}$ mouse to $13 \mathrm{kcal} / \mathrm{kg}$ body weight in a $600 \mathrm{~kg}$ cow.

In 1839 Sarrus and Rameau as well as Rubner (1883) formulated the "surface law" and stated that RMR in European animals amounted to $1000 \mathrm{kcal} / \mathrm{day} / \mathrm{m}^{2}$ of body surface. This was based on the assumption that the rate at which any warm body losses heat to its environment is a function of the area available for heat exchange and that heat production in a living organism must be equal to heat losses to maintain a constant body temperature. This would be logical if the surface of an animal's body was homogenous in its thermal insulation and its radiating characteristics, which is not the case. Another major criticism against the "surface law" is that the metabolically effective surface of animals has not been defined well. Different procedures used to measure the area of the skin (mould, planimeter of unstretched or moderately stretched skin after skinning) give results differing up to $50 \%$ (Kleiber, 1932). The definition of animal surface area is not precise: is it the radiating area or is it the area in contact with air? There are parts of the animal surface that, in a cold environment, have nearly the temperature of the surrounding air; should they be subtracted from the total surface area?

Taking into account all of these arguments Meeh (1879) proposed the general equation:

$$
\mathrm{S}=\mathrm{kW}^{2 / 3}
$$

where: $\mathrm{S}=$ surface area of animal body in $\mathrm{dcm}^{2}$

$\mathrm{W}=$ body weight in $\mathrm{kg}$

$\mathrm{k}=$ constant characteristic for groups of animals with a similar shape.

To avoid all of these uncertainties Krogh (1916) proposed abandonment of the ill-defined law of surface area altogether.

The second step towards resolving this issue was the proposal of the concept of "metabolic body size" as an exponential function of body weight. Stoeltzner (1928) suggested that the RMR of homeotherms was proportional to the 0.66 power of their body weight. This exponent was largely discussed by Benedict (1938) who modified it to the value of 0.75 as well as by Brody (1945) who proposed the power of 0.7 . The most known, now classical work in this field, was that of Kleiber (1947), who compared the RMR of 26 species of adult, non-producing animals from mouse to elephant and gave the following equation:

$$
\log \mathrm{H}_{\mathrm{kcal} / \mathrm{day}}=1.87+0.756 \log \mathrm{W}_{\mathrm{kg}}+/=0.05
$$

where: $\mathrm{H}=$ heat production in fasting state, at rest, in neutral zone of temperatures $\mathrm{W}=$ body weight. 
In non-logarithmic form this equation is presented in the following form:

$$
\mathrm{H}_{\mathrm{kcal} / \mathrm{day}}=70 \mathrm{~W}^{0.75} \text { or } \mathrm{H}_{\mathrm{kJ} / \mathrm{day}}=293 \mathrm{~W}_{\mathrm{kg}}^{0.75}
$$

In his 1938 book, Vital Energetics, Benedict criticized this logarithmic form of expressing a biological relationship and stated that although it may be correct from the mathematical point of view, it changes the variability and totally disguises the character of metabolic differences existing within species. The criticism of Benedict is very justified, because interspecies comparisons are much less important than intraspecies oncs. The body weight of a $600 \mathrm{~kg}$ cow is 2000 -fold greater than that of a $30 \mathrm{~g}$ mouse, but the body weight of cows varies from $300 \mathrm{~kg}$ to $600 \mathrm{~kg}$. The same relationship that is curvilinear on a very large scale is usually a simple linear one on a narrow scale and the logarithmic transformation of data changes their variability and clearly deforms the character of the statistical relationship, leading to erroneous conclusions.

From the statistical point of view the distinction between the two equations:

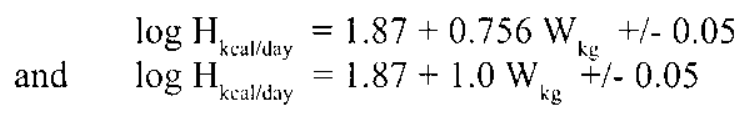

is only possible when the body weight of the smallest animal is at least $1 / 3$ lower than that of the biggest one (Kleiber, 1961). Adult farm animals within a particular species and race do not differ so much, so Kleiber's equation is not entirely appropriate for comparison of animals within one species.

\section{RESTING METABOLIC RATE AND LEAN BODY MASS}

When one is interested in metabolic ratedetermination, every attempt should be made to measure body composition.

Several authors express RMR as a function of fat-free body mass, which is assumed to be the closest approximation available of the respiring cell mass.

Bawa (1996) performed two experiments in young growing and aging rats (weighing from 145 to $417 \mathrm{~g}$ ) and computed relationships between resting metabolic rate and body mass, lean body mass, and protein body mass for 72 rats. $\mathrm{He}$ found 3 straight-linear regressions with correlation coefficients of $0.94(\mathrm{P}<0.00)$ in all cases. The implication is that this does not give a foundation for the use of lean body mass compared with the application of whole body weight or protein body mass, particularly when one studies the datum point for resting metabolic rate. Bawa (1996) also conducted a statistical analysis of the direct relationship between resting metabolic rate and the body fat percentage. The fat percentage in 
growing animals varied between 4.5 and $10.5 \%$ and did not correlate with resting metabolic rate $(r=0.07)$, but percentage body fat in the aging animals, varying from 7 to $25 \%$, was positively correlated with RMR ( $r=0.48)$.

Fürstenberg et al. (1997) and Fürstenberg (2001) applied and developed Keller's method in rats. It is based on inhibition of body weight growth up to a constant body weight (see below) and she formulated similar conclusions as Bawa did. She found linear regressions between resting metabolic rate and body weight, dry body mass, lean body mass and protein body mass in male and female rats of body weights ranging from 50 to $400 \mathrm{~g}$. Furthermore, she stated that the highest correlation $(r=0.70$ at $\mathrm{P}<0.00)$ for regression was obtained for body weight as compared with fat-free body mass $(r=0.65)$ or protein body mass $(r=0.65)$. Only the relationship between RMR and dry body mass had a slightly higher correlation coefficient $(\mathrm{r}=0.73)$ than that obtained for body mass itself. The studies of Fürstenberg et al. $(1997,2001)$ were done at $20^{\circ}-23^{\circ} \mathrm{C}$, i.e. below the critical temperature of the rat, but in the range of the environmental temperature usually applied in practice for breeding laboratory rats.

All of these results support the conclusion that adipose tissue is metabolically very active, and the "internal work" in obese is higher than in leaner-nonobese individuals because the respiratory and circulatory systems have to assure the proper functioning of the fat tissue.

\section{FASTING METABOLISM AND NUTRITIONAL MEMORY}

Steady-state maintenance is not typical for either farm or laboratory animals, so most experiments performed to measure fasting metabolic rate were carried out in growing, fattening, pregnant, lactating, laying, or working animals. The main problem in all of those experiments was probably related to the so-called metabolic or nutritional memory.

The fasting period before measurement was standardized as $12-18 \mathrm{~h}$ in men and rats, $24-48 \mathrm{~h}$ in poultry and pigs, and $48-72 \mathrm{~h}$ in ruminants. There is not much information concerning metabolic memory. However, it is known that its influence persists about 4 weeks in men (Kluszczyńska, 2001) and a few weeks in pigs (Junghans, 2000). If for example, a plane of nutrition continued for one month above the maintenance level is suddenly changed from a higher protein intake to a lower one (but always above the maintenance level), for a period of more than 3 weeks an adult organism excretes relatively higher amounts of nitrogen in urine than should result from the protein intake. If the plane of nutrition changes from the maintenance level to the higher one, an adult organism excretes smaller amounts of nitrogen in the urine than should result from the protein intake. Kleiber, in his classical book, The Fire of Life, demonstrated that in rats kept at 
$30^{\circ} \mathrm{C}$ the metabolic level decreased systematically from about $90 \mathrm{kcal} / \mathrm{W}_{\mathrm{kg}} 0.75 /$ day to $35 \mathrm{kcal} / \mathrm{W}_{\mathrm{kg}}{ }^{0.75} /$ day during 16 consecutive days of starvation, which can be easily interpreted as the effect of metabolic memory related to adaptation to lower energy intake. Johnson and Farrell (1982) found that restricted feeding could influence both the maintenance energy requirement of meat-type chicken as well as the efficiency of utilization of metabolizable energy for protein retention.

In the field of protein metabolism it is very well known that short-term starvation increases the rate of protein breakdown in the liver without influencing the protein synthesis rate, but decreases the protein synthesis rate in the muscles without changing to a greater extent the protein degradation rate. In growing pigs kept on an energy intake around the maintenance level as well as in lactating cows just after parturition, a positive protein balance and negative fat balance can be observed at the same time (Chwalibog, 1987).

All of these premises lead to the conclusion that the fasting metabolic rate in growing or producing organisms is not simply related to their metabolic body size, as proposed by Kleiber for adult non-productive animals of different species, but must be examined in a different way. There are many papers confirming this point of view, but only a few of them can be presented here.

\section{EXPERIMENTAL DATA DO NOT SUPPORT THE NOTION OF METABOLIC BODY SIZE}

Webster et al. (1976) calculated that fasting metabolic rate (FMR) measured over periods of 3-6 days in 8 growing steers over the range of $100-400 \mathrm{~kg}$ in weight was at the level of $450 \mathrm{~kJ} / \mathrm{W}_{\mathrm{kg}}^{0.75} /$ day $(+/-12.2)$, which was about $53 \%$ more than that calculated according to Kleiber's equation for adult, non-producing animals of different species.

Thorbek (1976) measured gas exchange and heat production in 71 barrows after 3-6 days of fasting in four liveweight groups (from 25 to $110 \mathrm{~kg}$ ) and at different environmental temperatures (from $16^{\circ}$ to $26^{\circ} \mathrm{C}$ ). A special attempt was made to estimate the exponent " $\mathrm{b}$ " in the regression equation

$$
\mathrm{H}_{\mathrm{kJ} / \mathrm{day}}=\mathrm{a} \mathrm{W}_{\mathrm{kg}}^{\mathrm{b}}
$$

based on all 71 measurements. Its average value was found to be

$$
\mathrm{b}=0.903+/-0.086 \text {, }
$$

which was significantly different from Kleiber's value of

$$
\mathrm{b}=0.756+/-0.05 \text {. }
$$


Values for "a" varied between 37.7 for younger pigs up to 65.3 for heavier ones. The rate of heat production was about $40 \%$ higher at a temperature of $18^{\circ} \mathrm{C}$ compared with $26^{\circ} \mathrm{C}$. For reasons of comparison, the equations for liveweight raised to powers of $0.750,0.667$, and 0.569 were calculated and it was concluded that, independently of the exponent used, it was not possible to include the observations from the lighter pigs $(25-30 \mathrm{~kg}$ ) in the functions used for 50 to $100 \mathrm{~kg}$ liveweight pigs.

Iwasaki et al. (1982), working on beef cattle, found that the average fasting metabolic rate in 17 heifers and cows immediately after parturition was $313 \mathrm{~kJ} /$ $\mathrm{W}_{\mathrm{kg}}{ }^{0.75} /$ day but in 9 non-pregnant cows RMR was $281 \mathrm{~kJ} / \mathrm{W}_{\mathrm{kg}}{ }^{0.75} /$ day. The average difference was about $11 \%$, but in the extreme it reached about $25 \%$; the fasting metabolic rate was always higher in producing than in non-producing animals.

Janji (1991) carried out 193 measurements of fasting metabolic rate in growing rats kept in two environmental temperatures and fed three isocaloric diets differing in protein to starch ratio. He found more significant influences of the studied factors (diet composition and environmental temperature) on fasting metabolic rate when RMR was expressed in $\mathrm{kcal} / \mathrm{W}_{\mathrm{kg}} /$ day than in $\mathrm{kcal} / \mathrm{W}_{\mathrm{kg}}{ }^{0.75} /$ day.

Bawa (1996) made 144 measurements of fasting metabolic rate in rats weighing from $145 \mathrm{~g}$ to $417 \mathrm{~g}$ and found a direct linear regression between RMR and body weight with a correlation of $r=0.94$. When $R M R$ was related to metabolic body size $\left(\mathrm{W}_{\mathrm{kg}}^{0.75}\right)$ the correlation was $\mathrm{r}=0.88$. The lower correlation shows that Kleiber's relationship should not be applied to young growing animals within taxonomic groups of homeotherms from the same species. Similar regressions between RMR and lean body mass or protein body mass were direct linear functions with correlation coefficients of $\mathrm{r}=0.94$.

When it comes to poultry, several authors (for example who presented their papers at the $8^{\text {th }}$ Symposium on Energy Metabolism in Farm Animals held in Lillehammer in Norway, 12-18 September 1982) demonstrated that under a wide variety of conditions laying hens require $400-500 \mathrm{~kJ} / \mathrm{W}_{\mathrm{kg}} 0.75 /$ day for maintenance, while the $\mathrm{ME}_{\mathrm{m}}$ of ducks was $880 \mathrm{~kJ} / \mathrm{W}_{\mathrm{kg}}{ }^{0.75} / \mathrm{day}$, and $\mathrm{ME}_{\mathrm{m}}$ of quail was $1140 \mathrm{~kJ} / \mathrm{W}_{\mathrm{kg}}{ }^{0.75} /$ day.

Keller (1977) found in growing chickens weighing from 300 to $1200 \mathrm{~g}$ that fasting metabolic rate expressed as a function of body weight in the double logarithmic scale gave curvilinear regression (the square effect was significant at the level of probability of $\mathbf{P}=0.05$ ), which was not possible for delogarithmization.

All of the examples cited above are quite sufficient to demonstrate that the relationship between fasting metabolic rate and metabolic body size proposed by Kleiber cannot be used for calculating the maintenance energy requirement of growing or producing animals within a taxonomic group for the same species. As a consequence, all partitioning of metabolizable energy intake between maintenance and production as well as all estimations of efficiency of energy retention or transformation into milk, eggs or physical work have to give us information that is rather distant from the facts. 


\section{PLANE OF NUTRITION AND FASTING METABOLIC RATE IN ADULT ANIMALS}

Energy balances near zero can be achieved over a long period in adult animals maintained on different feeding levels. For example, low ambient temperatures increase heat loss and animals correspondingly increase their feed intake to balance that increased energy expenditure. Hammond and Diamond (1997) defined "sustained metabolic rate (SusMR) as the time-averaged energy budget that an animal or human maintains over times sufficiently long that body mass remains constant because time-averaged energy intake equals time-averaged energy expenditure". There are, of course, some metabolic ceilings (different for particular species) that do not exceed five, maximum seven, times BMR over a long period.

Hammond and Diamond (1997) measured sustainable metabolic rate as well as resting metabolic rate in female mice influenced by low ambient temperature, litter size and running on a treadmill. They clearly demonstrated that a three-fold increase in sustainable metabolic rate was related to a two-fold increase in resting metabolic rate. The increased RMR at high SusMR was accompanied in that experiment by the hypertrophy of some energy-supplying organs, such as the small intestine, liver, kidneys and heart. It is well known that energy-consuming organs increase, selectively and reversibly, their mass during conditions of high sustained function: specific skeletal muscles grow in athletes during training, mammary glands grow during lactation, etc. Less evident, however, is reversible hypertrophy of central energy-supplying organs during any such condition of high SusMR. These central energy-supplying organs contribute a large fraction of an animal's RMR because of their very high mass-specific metabolic rates; in mice the kidneys have a mass-specific metabolic rate $51 \%$ higher than that of any other tissue, and the heart, small intestine, gut and liver are not far behind. Hammond and Diamond (1997) suggested that high SusMR requires an increased mass of energy-supplying organs, but that the high maintenance and operating costs of these organs cause them to contribute disproportionately to RMR, which thus tends to increase with SusMR.

\section{METHODS OF ESTIMATION OF MAINTENANCE ENERGY REQUIREMENT}

\section{Fasting experiments}

In fasting experiments, animals must be in a standardized postabsorptive state, must be kept in a thermoneutral environment and must show a minimum of locomotor activity. The main problem is to establish the ratio between the measured rate of fasting heat production in an animal in these circumstances and the amount 
of metabolizable energy of food needed to cover the animal's maintenance energy requirements. This problem can be divided into two sub-problems:

- the efficiency of utilization of metabolizable energy of food into net energy of basal metabolism, and

- the proportion between basal metabolism and diet-induced thermogenesis as well as energy cost of minimal locomotor activity.

A hundred years ago Oskar Kellner and his colleagues from Rostock were convinced that metabolizable energy of food was utilized for maintenance with an efficiency of $100 \%$. This assumption is not true, of course. Maintenance processes comprise muscular activity (smooth muscles, cardiac muscle, isometric contractions of skeletal muscles), active transport of metabolites across cellular membranes (especially in the digestive tract and kidneys), energy needed for anabolic processes (mainly for protein and fat turnover), as well as transduction of impulses in the nervous system. All these processes need ATP (but not heat) and the synthesis of ATP is not closely related to heat production. The oxidation of $1 \mathrm{~g}$ of carbohydrate and of $1 \mathrm{~g}$ of protein results in the production of the same amount of heat (on average), but the amounts of ATP synthesized in these two processes, and available for all of the free-energyconsuming processes cited above, are about three-fold different.

Dietary induced thermogenesis is not a function of metabolic body size, nor is it directly related to the metabolizable energy of food, but it is influenced by the chemical composition of a diet, being greatest after protein intake, and smallest after fat intake; DIT also depends on the dietary fibre content.

The energy cost of physical activity is a direct linear function of animal body weight, but depends on the speed of locomotor activity and on environmental temperature, so its relation to metabolic body size is not so simple.

The general conclusion is that the utilization of metabolizable energy of food for maintenance is not a constant one, is less than $100 \%$, and depends on the chemical composition of food, being more related to animal body mass itself than to metabolic body size.

\section{Feeding experiments at near-zero levels of energy retention}

The value of the maintenance energy requirement can also be estimated from experiments with animals kept on a feeding level near that of maintenance. From the theoretical point of view this method requires knowledge about the partial efficiencies of metabolizable energy utilization for the retention of protein $\left(\mathrm{k}_{\mathrm{p}}\right)$ and fat $\left(k_{r}\right)$. The values $k_{p}=0.5$ and $k_{f}=0.8$ are usually accepted in rats as well as in pigs and calves, but the errors are of minor importance only when the energy retained in the animal's body does not exceed $5 \%$ of the total $\mathrm{ME}$ intake. The values of $\mathrm{ME}_{\mathrm{m}}$ are calculated using the formula: 


$$
\mathrm{ME}_{\mathrm{m}}=\mathrm{ME}-\mathrm{RPE} / \mathrm{k}_{\mathrm{p}}-\mathrm{RFE} / \mathrm{k}_{\mathrm{f}}
$$

where: $\mathrm{ME}_{\mathrm{m}}=$ metabolizable energy for maintenance

$\mathrm{ME}=$ metabolizable energy intake

$\mathrm{RPE}=$ energy retained as protein

$\mathrm{RFE}=$ energy retained as fat.

This method offers some special advantages mainly in non-producing dairy cows and laying hens, but can not be applied in growing animals such as pigs, calves or chickens.

Chwalibog (1987) compared data presented by different authors in 41 papers published from 1977 to 1985 and stated that values of $\mathrm{kp}$ varied from 0.38 to 0.63 in chickens and from 0.75 to 0.97 in pigs.

Fowler and Fuller (1979) also compared experimental data of several authors working with growing pigs and demonstrated that $\mathrm{k}_{\mathrm{p}}$ values varied from 0.35 to 0.80 , decreasing with the body weight of animals, whereas $\mathrm{k}_{\mathrm{f}}$ values varied from 0.70 to 0.91 showing a bit greater stability.

From the practical point of view this range of variability makes it impossible to draw conclusions that could be important in animal nutrition.

Feeding experiments on different feeding levels

The general assumption of this approach is that maintenance energy requirement $\left(\mathrm{ME}_{\mathrm{m}}\right)$ is only determined by the size of animals and that there is a linear relation between metabolizable energy intake (ME) and net energy retention (RE), i.e. that efficiency of energy utilization is assumed to be entirely a function of the diet. It is calculated according to the model:

where: $\mathrm{a}=\mathrm{Me}_{\mathrm{m}}$

$$
\mathrm{RE} / \mathrm{W}_{\mathrm{kg}}{ }^{0.75}=\mathrm{a}+\mathrm{b} \mathrm{ME} / \mathrm{W}_{\mathrm{kg}}{ }^{0.75}
$$

$b=$ energetic efficiency of energy retention $\left(k_{p f}\right)$ in growing animals.

This model is based primarily on two main assumptions, both of which are unacceptable.

First, this model assumes that the efficiencies of ME utilization for protein retention $\left(\mathrm{k}_{\mathrm{p}}\right)$ and fat deposition $\left(\mathrm{k}_{\mathrm{f}}\right)$ are identical, which is not true, because $\mathrm{k}_{\mathrm{p}}$ is generally smaller than $\mathrm{k}_{\mathrm{f}}$. This problem would not have been relevant if the proportions between energy retained in protein and fat were constant during the whole experimental period, but it is questionable whether that is possible at all, because in growing animals protein retention has a priority against fat deposition. Thorbek 
and Chwalibog (Chwalibog, 1987) found positive energy retention and negative fat balance at the same time in young pigs.

Second, feeding experiments on different planes of nutrition assume the extrapolation of $\mathrm{ME}$ to $\mathrm{RE}=0$. It has been mentioned above that the state of energy equilibrium $(\mathrm{RE}=0$ ) can easily be achieved with some protein retention and body fat mobilization. This assumes that ATP provided by catabolism of ingested nutrients and ATP provided by catabolism of fat reserves in the body can be added, but efficiencies of ATP production from each of these two sources are different.

Some authors use the reverse model of the equation cited above, assuming that $\mathrm{ME}$ is the dependent variable:

$$
\mathrm{ME} / \mathrm{W}_{\mathrm{kg}}^{0.75}=\mathrm{a}+1 / \mathrm{k}_{\mathrm{pf}} \mathrm{RE} / \mathrm{W}_{\mathrm{kg}}^{0.75}
$$

This assumption is not biologically acceptable and regression calculated according to that model cannot be precise.

\section{Partitioning of me in growing or producing animals}

This method of estimation of maintenance energy requirement is based on the assumption that metabolizable energy intake (ME) can be partitioned into three separate components in growing or producing animals:

- energy requirement for maintenance $\left(\mathrm{ME}_{\mathrm{m}}\right)$,

- energy requirement for protein retention (1/b, RPE),

- energy requirement for fat deposition ( $\left.1 / \mathrm{b}_{2} \mathrm{RFE}\right)$.

Maintenance energy requirement is then calculated from a number of multiple regression models:

$$
\mathrm{ME}=\mathrm{ME}_{\mathrm{m}}+1 / \mathrm{b}_{1} \mathrm{RPE}+1 / \mathrm{b}_{2} \mathrm{RFE}
$$

where , $1 / \mathrm{b}_{1}$ " and , $1 / \mathrm{b}_{2}$ " mean partial efficiencies of utilization of metabolizable energy for protein retention and fat deposition.

This method requires that the ratios RPE:PFE show some contrasts in the composition of retained energy in experimental animals, which must be due to different levels of energy intake only.

The main problem in those estimations of $\mathrm{ME}_{\mathrm{m}}$ is the assumption that the relationships between protein and fat retention and $\mathrm{ME}$ intake above maintenance have regressions of a linear character; as a consequence they are expressed by constant "k" values with a zero point for all variables. One can accept the relatively smaller variability of " $\mathrm{k}_{\mathrm{f}}$ " but there are many papers showing the great variability of " $\mathrm{k}_{\mathrm{p}}$. A number of examples have been presented above to confirm this range of variability. 
Maintenance energy requirements in growing or producing animals are not only a function of body size, but are influenced as well by plane of nutrition, which was clearly demonstrated by Gray and McCracken (1979). In their experiments the mean values of $\mathrm{ME}_{\text {in }}$ (corrected to zero energy balance) calculated for $25 \mathrm{~kg}$ pigs previously fed at metabolizable energy intake levels equaling 2-, 2.5-, 3-fold maintenance $\left(2 \mathrm{xME}_{\mathrm{m},} 2.5 \mathrm{xME}_{\mathrm{m},} 3 \mathrm{xME}_{\mathrm{m}}\right)$ were respectively, $407,470,481 \mathrm{~kJ} /$ $\mathrm{W}_{\mathrm{kg}}{ }^{0.75}$ and the uncorrected values of $\mathrm{ME}_{\mathrm{in}}$ calculated for $10 \mathrm{~kg}$ pigs previously fed $2 \mathrm{xME}_{\mathrm{m}}$ or $3 \mathrm{xME}_{\mathrm{m}}$ were 579 and $667 \mathrm{~kJ} / \mathrm{W}_{\mathrm{kg}}^{0.75}(\mathrm{P}<0.01)$.

Thorbek et al. (1982), working with 26 growing pigs, showed that $\mathrm{ME}_{\mathrm{m}} / \mathrm{W}_{\mathrm{kg}} 0.75$ was not constant from 12 to $20 \mathrm{~kg}$ liveweight of animals, but decreased from about 600 to $440 \mathrm{~kJ} / \mathrm{W}_{\mathrm{kg}}{ }^{0.75}$. They proposed to use a linear function of $\mathrm{W}_{\mathrm{kg}}{ }^{0.75}$ with a constant term as follows:

$$
\begin{gathered}
\mathrm{ME}_{\mathrm{m.k \textrm {k }} \mathrm{d}}=4060+210 \mathrm{~W}_{\mathrm{kg}}^{0.75} \\
\mathrm{RSD}=368 \quad \mathrm{CV}=4,8 \% \quad \mathrm{R}^{2}=0.95
\end{gathered}
$$

In experiments carried out on 88 growing chickens Keller (1980) expressed the fasting metabolic rate ( $\mathrm{FM}$ in $\left.\mathrm{kJ} / \mathrm{W}_{100 \mathrm{~g}} / \mathrm{h}\right)$ as a function of the relative rate of growth of body weight ( $\mathrm{G}=$ daily gain of body weight as per cent of actual body weight). The exponential equation was calculated as follows:

$$
\mathrm{FM}=76.6+36.2 \mathrm{G}-3.23 \mathrm{G}^{2} \quad \mathrm{r}=0.94
$$

A suggestion has been made that the relative rate of growth of body weight should be taken into account in all considerations on the maintenance energy requirement in growing chickens because it seems to be a better criterion than body weight.

Inhibition of body weight growth up to constant body weight

Keller (1969) has proposed a new method of estimation of feed for maintenance in growing chickens based on feeding them a constant daily ration of feed up to the moment when their daily gain of body weight reaches zero, this daily ration of feed is their feed for maintenance. Animals were on a decreasing plane of nutrition for considerable lengths of time and adapted their metabolism to the low level of nutrition, which made it possible to avoid the influence of nutritional memory on resting metabolic rate. Because several groups of chickens were fed several constant daily rations of feed, a linear regression of the type

$$
y=a+b x
$$

was found between the chickens' maximal body weight $(y)$ and the constant daily ration of feed $(x)$ being the feed for maintenance. The general conclusion is that 
the relationship between the feed for maintenance and the body weight in growing chickens is of a linear character, not a curvilinear one.

A similar regression has been found by Fürstenberg $(1997,2001)$ for growing rats in a series of experiments performed in male and female animals of body weights ranging from 50 to $400 \mathrm{~g}$ fed on different constant stipulated feed rations $\left(\mathrm{ME}_{\mathrm{m}}\right.$ in $\left.\mathrm{kJ}\right)$ up to constant body weight $\left(\mathrm{W}_{\mathrm{kg}}\right)$ :

$$
\mathrm{W}_{\mathrm{kg}}=0.000765 \mathrm{~kJ} \mathrm{ME}_{\mathrm{m}}+0.01587(\mathrm{r}=0.84) \text {. }
$$

Based on final body weights reached at these rations and measurements of RMR she also found a smaller requirement for maintenance in growing male rats as compared to growing female rats at the same body weight:

$$
\begin{aligned}
& \text { for males: } \quad \mathrm{W}_{\mathrm{kg}}=0.000875 \mathrm{~kJ} \mathrm{ME}_{\mathrm{m}}+0.00483 \quad(\mathrm{r}=0.97) \\
& \text { for females: } \mathrm{W}_{\mathrm{kg}}=0.000480 \mathrm{~kJ} \mathrm{ME} \mathrm{n}_{\mathrm{n}}+0.06940 \quad(\mathrm{r}=0.84) \text {. }
\end{aligned}
$$

This result is very interesting, because the metabolism of all animals was adapted to the decreasing plane of nutrition for considerable lengths of time, when protein retention was at a minimum and fat deposition did not exist at all; the differences observed between the males and the females were related really with resting metabolic rate itself.

Starting from the method cited above, Keller $(1969,1973)$ stated as well that the regression between daily protein retention and daily feed for growth in chickens was of a curvilinear character; as a consequence, the energy cost of protein retention varied from 4.8 to $13.1 \mathrm{kcal} \mathrm{ME}$ per gram of protein retained, being influenced by growth rate and diet composition.

\section{CONCLUSIONS}

Maintenance energy requirements in animals, expressed in metabolizable energy of food $\left(\mathrm{ME}_{\mathrm{m}}\right)$, are related to resting metabolic rate (RMR), dietary induced thermogenesis (DIT) and cnergy cost of normal physical activity (EEPA). In most expcriments, as well as in practical nutrition, $\mathrm{ME}_{\mathrm{m}}$ is calculated from resting metabolic rate (RMR) multiplied by 1.40. RMR in animals is influenced by body size, gender, genotype, and nutritional memory (plane of nutrition before the measurement).

Brody and Kleiber - comparing RMR in adult non-producing animals from 26 different species - proposed the so-called "metabolic body size" and general equation as follows

$$
\mathrm{RMR}_{\text {kcal/day }}=70 \mathrm{~W}_{\mathrm{kg}}^{0.75}
$$




$$
\text { or } \mathrm{RMR}_{\mathrm{kJ} / \mathrm{day}}=293 \mathrm{~W}_{\mathrm{kg}}^{0.75}
$$

Many papers indicate that this equation can be useful for inter-species comparisons only, but should not be used for estimation of maintenance energy requirements in growing or producing animals within taxonomic groups of homeotherms from the same species, which is much more interesting from the practical point of view.

There are actually enough experimental data to propose the use of simple linear regressions for predicting $\mathrm{ME}_{\mathrm{m}}$ in growing or producing animals within some species. It should give more precise estimations of $\mathrm{ME}_{\mathrm{m}}$ than the use of ten logarithmic regression, "RMR $=\mathrm{a} \mathrm{W}^{\mathrm{b}}$.

The method of growth rate inhibition seems to be an interesting one for some basal research and should be developed in different animal species.

Being still far from quite precise estimation of maintenance energy requirement, we need more theoretical research to evaluate the influence of plane of nutrition and gender, not only body size, on $\mathrm{ME}_{\mathrm{m}}$.

\section{REFERENCES}

Bawa S.H., 1996. Energy expenditure in animals varying in percentage body fat. Ph.D. Thesis, Warsaw Agricultural University. Library

Bayley H.S., 1982. Energy metabolism in birds. Proceedings of $9^{\text {th }}$ Symposium on Energy Metabolism of Farm Animals. Lillehammer (Norway), pp. 158-162

Blaxter K.L., 1972. Fasting metabolism and energy requirement for maintenance. In; Festskrift til Knud Breirem. Mariendats Boktrykkeri, A.S. Gjovik (Norway), pp. 19-36

Brody S., 1945. Bioenergetics and Growth. Reinhold, New York

Chwalibog A., 1987. Notes on maintenance requirement and utilisation of energy. Lectures in Japan. Personal communication

Delage J., 1972. Energetique. INA, Paris-Grignon (France)

Fowler V.R., Fuller M.F., 1979. Encrgy requirements for the growing pig. In: L.E. Mount (Editor). Energy Metabolism. EAAP Publication No. 26, Butterworths, London-Boston, pp. 151-156

Fürstenberg E., 2001. Maintenance energy requirement of growing rats as a function of body mass, body composition and gender. In: A. Chwalibog K. Jakobsen (Editors). Energy Metabolism in Animals. EAAP Publication No. 103. Snekkersten (Denmark), pp. 51-54

Fürstenberg E., Keller J.S., Bujko J., Halilu Bawa S., 1997. Maintenance energy requirement as a direct linear function of body weight. Z. Emährungswiss. 36, 322

Gray R., Mc Cracken K.J., 1979. Plane of nutrition and the maintenace requirement. In: L.E. Mount (Editor). Energy Metabolism. EAAP Publication No. 26, Butterworths, London-Boston, pp. $163-169$

Hammond K.A., Diamond J., 1997. Maximal sustained energy budgets in humans and animals. Nature, 386, 457-462

Iwasaki K., Haryn T., Kameoka K., 1982. The fasting energy metabolism in pregnant and non-pregnant beef cattle. Proceedings of $9^{\text {th }}$ Symposium on Energy Metabolism of Farm Animals. Lillehammer (Norway), pp. 152-155 
Janji G., 1991. The influence of protein level in the diet and environmental temperature on metabolism relating to physical activity in laboratory ral (in Polish). Ph.D. Thesis, Warsaw Agricultural University. Library

Jolnson, Farrell, 1982. The effects of restricted feeding on the energy metabolism of layers. Proceedings of $9^{\text {th }}$ Symposium on Energy Metabolism of Farm Animals. Lillehammer (Norway), pp. 161-164

Junghans P., 2000. Personal communication

Keller J.S., 1969. Croissance ponderale des poulets en fonction de la consommation de la ration de croissance. Ann. Biol. Anim. Bioch. Biophys. 9, 393-404

Keller J.S., 1977. Body weight and metabolic level in growing chickens. Acta Physiol. Pol. 28, $575-583$

Keller J.S., 1980, Fasting heat production as a function of growth rate in chicken. Arch. Geflügelk. $44,168-172$

Keller J.S., Wagner J., 1973. Influence du genotype sur l'efficacite nutritionnelle des aliments pour le poulet de chair. I. Rapport optimum entre l'apport energetique et azote pour l'entretien. Ann. Zootech. 22, 93-102

Kiclanowski J., 1972. Protein requirement of growing animals. In: W. Lenkiet, K. Breirem, E. Crasemann (Editors). Handbuch der Tierernährung Vol, Ii. Paul Parey Verlag. Hamburg-Berlin, pp. $528-546$

Kielanowski J., 1976. Energy cost of protein deposition. In: K.N. Boorman, P.J. Buttery, D. Lewis, R.J. Neale, H. Swan, D.J.A. Cole (Editors). Protein Metabolism and Nutrition. Butterworths, London-Boston, pp. 207-215

Kleiber M., 1932. Body size and metabolism. Hilgardia 6,315-353

Kleiber M., 1947. Body size and metabolic rate. Physiol. Rev. 27, 511-541

Kleiber M., 1961. The Fire of Life. Joln Wiley and Sons, Inc., New York-London

Kluszczyńska D., 2001. Nutritional memory for protein metabolism in man. Personal communication

Mac Lcod M.G., 1984. Factors influencing the agreement between thermal physiology measurements and field performance in poultry. Arch. Exp. Vet. Med. 38, 399-410

Mech K.U., 1879. Oberflächenmessungen des menschlichen Körpers. Z. Biol. 15, 425-458

Rubner M., 1883. Über den Einfluss der Körpergrösse auf Stoff- und Kraft-wechsel. Z. Biol. 19, $535-562$

Stoeltzner W., 1928. Schriften der Königsberger gelehrten Gesellschaft Naturwiss. K1. 5, 145-164

Thorbek G., 1976. Energy metabolism in growing pigs at different liveweight as influenced by temperature. In: M. Vermorel (Editor). Proceedings of $7^{\text {th }}$ Symposium on Enery Metabolism of Farm Animals. Vichy (France), pp. 147-150

Thorbek G., Chwalibog A., 1982. Energy requirement for maintenance and growth in pigs from 20-120 kg liveweight. Proceedings of $9^{\text {th }}$ Symposium on Energy Metabolism of Fann Animals. Lillehammer (Norway), p. 51

Thorbek G., Chwalibog A., Henckel S., 1984, Nitrogen and energy metabolism of Danish Landrace from 20 to $120 \mathrm{~kg}$ live weight. Beretning 563 , Statens Husdyrbrugsforsog, pp. 114

Webster A.J.F., Brockway J.M., Smith J.S., 1976. Energy exchange during growth in cattle. Proccedings of $7^{\text {th }}$ Symposium on Energy Metabolism of Farm Animals. Vichy (France), pp. 135-138 


\section{STRESZCZENIE}

\section{Zapotrzebowanie na energię bytową przez dorosle i rosnące organizmy - nie rozwiązany pro- blem}

Tempo metabolizmu jest wyrażane jako tempo produkcji ciepła będącej efektem wszystkich procesów oksydacyjnych zachodzących w organizmie. Procesy te dzieli się na procesy bytowe i produkcyjne, przy czym podział ten oparty jest na założeniu, że obydwa te rodzaje procesów są od siebie niezależne, a więc mogą się sumować. Potrzeby bytowe wyrażane są zwykle jako funkcja rozmiarów ciała, natomiast koszt energetyczny procesów produkcyjnych wyrażany jest w przeliczeniu na jednostkę ,produktu” (najczęściej odłożonego białka i tłuszczu). Dotyczy to w zasadzie organizmów dorosłych, charakteryzujących się niskim poziomem aktywności fizycznej, niskimi wydatkami energetycznymi i zerowym bilansem azotowym i tylko w pewnych okresach życia odkładaniem tłuszczu w ciele. Liczne badania wskazująjednak na wpływ procesów anabolicznych na procesy kataboliczne oraz istnienie pamięci metabolicznej; w metabolizmie białkowym szeroko znane jest zjawisko anabolicznego wzrostu katabolizmu, a pamięć metaboliczna, w świetle licznych doświadczeń, utrzymuje się nawet powyżej 30 dni.

W świetle powyższego nie wydaje się uzasadnione oddzielne rozpatrywanie procesów bytowych i produkcyjnych w odniesieniu do organizmów rosnących należących do tej samej grupy taksonomicznej.

W pracy proponuje się nową metodę szacowania bytowego zapotrzebowania na energię rosnących zwierząt. Polega ona na karmieniu zwierząt stałymi dawkami paszy i wyznaczaniu maksymalnej masy ich ciała, przy której dawki te pokrywają tylko zapotrzebowanie bytowe i nie zawierają nadwyżek na wzrost. 